\title{
Polarized Discourse in Pajhwalk and Kabul Times news
}

\section{Mohammad Naeem Wisal}

Teaching Assistant Prof, Pashto Department, Education Faculty, Paktia University, Afghanistan Email: nhasaand@gmail.com

Phone: 0093773545858

\begin{abstract}
:
The main purpose of the study is to investigate about the conceptual structures of polarized discourse coded in the reports of two online Afghan news Pajhwalk and Kabul Times, this study focuses on the online news reports relating to the peace. The main and hot issue in the news nowadays are peace in Afghanistan.

This investigation probes to find answer for the following questions: Does the claim of Van Dijk's (1998, p.33) conceptual rectangular expose the use of 'polarized discourse' in both sites?, If yes, is this 'polarized discourse' drew in positive lengthy performs like quotation patterns and labeling?. The analysis of this report is conducted within the framework of Critical Discourse Analysis. The structures of the principles of the polarized discourse are drew through quotation and patterns and labeling. This study concludes with the discussion on how both websites establish a dichotomy of 'we' versus 'them'. Moreover, the reports of every site minimize the other through what is named 'Missing News'.
\end{abstract}

Keywords: Polarization, Quotation patterns, Labeling, CDA, News, Conceptual. 


\section{Introduction}

One of the most problem or major challenges in Afghanistan is insecurity. The frequency of rubbery, war, kidnapping and murder, and common war seem to be devastating both that sate and citizens of the country. Investors in Afghanistan including those in dispersion, as well as friends from the international community such as China, USA, Russia, and etc, they are also concerned about the security and peace in Afghanistan. They are working hard to find a proper solution for the current situation in Afghanistan and trying how to bring sustainable peace and development in Afghanistan. Recently, a complicated method is being approved. While the legislative reviews are ongoing for me suitable laws and roles to deal with the recent challenges and problems. law Enforcement Agents and agencies and peace council are also trying hard to find a way for the current situation and put end to this situation. Criminality in every aspect is sufficiently authorized, so as to minimize crime. In addition, all these, are very powerful effort is also being made to ensure that children of school age are also enrolled in the school, at least for the first 17 years there are more development in the field education and in construction.

Since October 252018 to December, 25, 2018, the Afghan government and some international friend countries has been in the limelight for its uniqueness and the important changes in the Afghanistan. This particular changes is to bring peace in the Afghanistan which is very important and needed thing for Afghans after passing long time war in the country. To be precise there has been a 'media war' between different online and other medias. The mass media played an important role in excavating points of difference and polarization foremost a tug-of-war.

In this framework, this study detects the different forms of the polarized discourse presented in the news reports by the two news websites: Pajhwalk and Kabul Times. The basis overdue choosing those websites in the specific is their image of the two ideologies. Pajhwalk is official English, Pashto and Dari online website which is publishing online from Kabul and presents the news reports in three languages, and also Kabul Times is official English website, publishing news only in English.

Through the complete quantitative and qualitative research of news reports in the both news websites, this investigation probes to find answer for the following questions. 
1. Does the claim of Van Dijk's (1998, p.33) conceptual rectangular expose the use of 'polarized discourse' in both sites?

2. If yes, is this 'polarized discourse' drew in positive lengthy performs like quotation patterns and labeling?

\section{Data collection}

This research detected different kinds of news in the both websites for a one month from October 25, 2018, to December, 25, 2018, and then its classified events according to their relatedness. In the other words, the selected events are related to each other, even in as a result or a reason. This event is peace which is recently more important and needed in Afghanistan.

1. Bringing to peace to Afghanistan by the support of different international countries.

Chronologically this event is the starting point of positive and hopeful for Afghans which is announced by the USA and some other countries that they are going to work hard to bring peace to Afghanistan. Different meetings are organized in some countries they talked about the importance and the way how to bring peace and what are the conditions for both sides Taliban and government. Some of the countries will play important role in bringing peace to Afghanistan such as China, Russia, USA, Pakistan and some other neighbor countries. This topic is more interesting and hot issues in the news that's why I have select the topic find out the polarized discourse in the two online websites: Kabul Times and Pajhwalk. The arguments over this topic is clearly established in the news reports of both sites.

The data collected from both websites can summarized in the Table (1) bellow:

\begin{tabular}{lll}
\hline Source & No, news reports & No, words \\
\hline Pajhwalk & 20 & 10280 \\
\hline Kabul Times & 30 & 14560
\end{tabular}

It's noteworthy, that this data is investigated quantitative and qualitative to answer the research questions.

\section{Theoretical Framework}

This research accepts Critical Discourse Analysis (CDA) as its analytic pattern concentrating on the works of Fairclough (1995b), Fowler et al. (1991) and Van Dijk (1988, 1993, 
1998, 2000). In its spirit, CDA proceeds from the idea of mere account of structural forms of discourse to relating these forms to social practices.

Critical linguistic, according to fowler, (1991).

Critical linguistic basically means an investigation into the relatives between meaning, signs and the social and historical situations which rule the semiotic structure of discourse, using a specific kind of linguistic analysis (p.5).

Therefore, CDA caries the idea that society is not only formed by discourse; it also forms this discourse. However, the main purpose of the critical discourse analyst is to unload the different ideologies connection between broad practices and the social practices.

In this setting, more description is need of the word 'critical', which is a key term in our theoretical framework, i.e. CDA. The idea of criticality in CDA provides this diagnostic method a very critical function, which is authorizing social contributors with tools to unpack 'opaque' ideologies found in the discursive practices of those in power (Fairclough, 1995, p.54).

An exclusive surface of this investigation is its necessity on web-based data, i.e online news. It signifies an influence to what may be labelled as web-based Critical Discourse Analysis (WBCDA). Maunter (2005) relates to the shortage of Critical Discourse Analysis studies using online data.

However, universally web has become more developed a widespread tool and object for the different types of linguistic and semiotic research, Critical Discourse Analysis (CDA) does not seem and share this kind of eagerness in equivalent measure. The modern significance of the web as a very important site for enunciation of social issues should make it a major target for a CDA with the emancipatory and political brief. (p.809).

In this specific, we should mark the truth or fact that 'news' is one of the most important personifications of these kind of impervious conceptual, especially those of unsatisfactory relations of power or influence. The idea of giving incapable relatives of power or demeaning 'the other' is attempted by many researches, such as those by Achugar (2004), Belkau (2006), Cheng(2002), Flowerdew (2002), Juan (2009), Joye (2010), Jullian (2011), Kuo and Nakamura (2005), Khorsravinik (2009), Rasti and Sahragard (2012), Teo (2000) and Thetela (2001). 
All the upper stated studies or researches have the common line of thoughts which are description of how the 'other' is presented through the CDA in different levels actors and events of the news.

In this framework, the idea of the 'ideological square' (Van Dik, 1998) appears to be attractive. In the 'ideological square', Dijk accepts the idea of giving positive-self and negative other. In other words, he studies the policies of foregrounding positive performs of oneself and deemphasizing any positive feature of the other. This study contends that the policy of polarization is obviously established in the polarized discourse accepted by both websites under the examination, i.e Kabul Times and Pajhwalk. Although, this study reflects that this polarized discourse is personified in two discursive practices, namely.

- Quotation patterns

- Labeling

\section{Analysis and Discussion:}

\section{Quotation patterns}

Quotation patterns assume a significant job in shaping news as they are the crude material out of which a columnist passes on a specific message to his peruses. These quotations reflect belief systems of the two correspondents and their associations. At the end of the day, citations can't be viewed as negligible references of newsmakers citing (Bell's 1991) phrasing. Van Dijk (1991) stresses a similar thought contending that "source writings not just component representations, translations or declarations of occasions and activities, yet in addition evaluative explanations, that is, opinions"(p.152). This investigation views citation designs as solid ideological apparatuses which can be utilized to coordinate peruses' elucidation to a specific bearing which, thus, prompts the polarization of these peruses into two gatherings for example 'in' what's more, 'out' gatherings. The polarization of peruses can be accomplished, using citations, in three different ways, though, the choice of sources quoted, the choice of reporting verbs and the choice of quotation types.

The primary component that exemplifies confidence system in quotation designs is the sort of quotation received by correspondents. In this regard, Richardson (2007, pp.102- 106) groups quotation into five kinds. The primary sort is 'immediate citation' which is for the most part used to introduce news as realities. 
The second kind is what is named as 'vital quotation' in which a columnist utilizes 'terrify statements' to demonstrate the combative idea of the words cited. The third kind is 'roundabout citation' in which a correspondent outlines information disclosed or composed by the first newsmaker. The fourth kind is 'the changed circuitous citation' in which the columnist drops detailing action words like 'say' or 'tell'. The last kind is the 'apparent direct citation' in which a columnist makes up the substance of the quotation to pass on a certain message.

Richardson further builds up this characterization by envisioning "a dynamic line of exactness" with direct quotation toward one side and apparent citations at the opposite end. The more we move far from direct quotation, the more prominent the likelihood of twisting of the first talk. Figure (1) underneath represents Richardson's dynamic line of precision:

Applying Richardson's grouping of quotation to information under scrutiny, three fundamental sorts are distinguished, immediate, backhanded and vital quotation. We can observe the results in the bellow table: table 2

\begin{tabular}{cll}
\hline Reference & Type & Frequency \\
\hline \multirow{3}{*}{ Kabul Times } & Direct & 85 \\
& Indirect & 90 \\
& Strategies & 45 \\
\hline \multicolumn{1}{c}{ Total } & & 220 \\
\hline \multirow{2}{*}{ Pajhwalk } & Direct & 35 \\
& Indirect & 30 \\
& Strategies & 4 \\
\hline \multicolumn{1}{c}{ Total } & & 69 \\
\hline
\end{tabular}

An examination of the table (2) uncovers various certainties. Right off the bat, the Kabul times reports utilized progressively 'coordinate' quotations than the Pajhwalk.

This is possibly clarified in the light of giving greater facticity to the reports as "a statement is esteemed as an especially indisputable actuality" (Bell, 1990, p.207). besides, the Kabul Times utilized 'backhanded' citations more than the Pajhwalk.

In this regard, Richardson's (2007) line of precision may display a clarification. The journalists of Kabul Times will in general utilize circuitous citations to give them greater adaptability in the translations of newsmakers' words. 
In this way, they have more powers to coordinate their own peruses as per their belief systems. Thirdly, it is clear that the columnists of the Kabul times utilized multiple times the quantity of 'vital' citations as those writing in the Pajhwalk. The two sites utilized distinctive sorts of citations for ideological finishes. Columnists of the two locales utilized citations as " a door keeping gadget that concedes just those in places of intensity" (Teo, 2000, p.41). this thought is apparent in the substance of citations.

The followings are some examples that can show the cases and give more illustrations:

\section{Kabul Times:}

1. "Terrorists and other armed opponent groups supported by any sides cannot challenge determination of the people of Afghanistan, but instead it increases morale among the people to defend the country and sovereignty," NSA Hamdullah Mohib said.

2. Pakistani Foreign Minister Shah Mehmood Qureshi and his delegation met with President Mohammad Ashraf Ghani in Kabul here yesterday, Presidential Palace said in a statement. The opposite sides examined Afghanistan-Pakistan relations, respective issues, Afghandrove and Afghan-claimed harmony process and following stages after intra-Afghan talks, the announcement said.

The first example is a report on the Those saying "no" to peace will be suppressed, security officials. The head of NSA Hamdullah Mohib, who is an outstanding figure in the Afghan government is directly quoted, only to be condemned by the news reporter who fuses his idea about the moral of Afghan people for their future and defending their country from terrorists. The words of Hamdullah Mohib he represents a frame for the accusations levelled against the people of Afghanistan.

In the second example, the Pakistani Foreign Minister Shah Mehmood Qureshi and his delegation met with President Mohammad Ashraf Ghani. In addition, they only thing that which was important and they have discussed about it was peace. They have discussed about the relation of Pakistan and Afghanistan they will create the atmosphere for 'we' the protectors of rebellion, and 'them' the anti-revolutionists. 
However, the fact that the Pajhwalk follows the same method of quoting with the other in order to criticize, it is unique in its use of the 'strategic' or 'scare' quotations. This idea can be exemplified as the following:

3. President Ashraf Ghani has said peace can pave the way for great investment opportunities in Afghanistan and that the reconciliation process could not be hidden from the public. A statement from the Presidential Palace received by Pajhwok Afghan News said that President Ghani met with leading traders as part of his consultative meetings on the peace process on Wednesday evening. The gathering was attended to by acting Afghanistan Chamber of Commerce and Industry (ACCI) head Khan Jan Alokozay, Women's Chamber of Comemrce and Industry head Manija Wafiq, Chamber of Industryand Mines head Sherbaz Kaminzada and an investor Zabihullah Ziarmal, who welcomed the president's efforts about the peace process.

4. Sadar said their assessment and analysis showed all peace related programs regarding Afghanistan during the past 17 years particularly before 2014 had been a failure. He said during this period the Afghans eluded decisiveness for making peace in their country and the only achievement was the Hezb-i-Islami Afghanistan's joining of the peace process.

5. Newly-appointed High Peace Council secretary Omar Daudzai on Wednesday said peace would be coming to Afghanistan in the next few months. Daudzai, also special presidential representative for regional consensus on peace, formally took charge of his offices at a gathering in Kabul.

In the first example president Ashraf Ghani said that the pave of pave has not been hidden from the government. He said that everything has to be told to the public. President Ashraf Ghani is quoted to be criticized through the use of scare quotes. Most of the reporters are not agree with his view that protesters are wasting of Kabul Times.

Again in the example (4), is quoted to be marginalized. The statement is quoted to be criticized. This criticism is reflected in two points. Firstly, the use of reporting verbs in the statement to which it relates. Secondly, it provides proof of the invalidity of the claims. This proof is the focus of president on the topic how to bring peace in the Afghanistan. 
Academic Journal of Research and Scientific Publishing | Vol 3 | Issue 34

Publication Date: 5-2-2022 ISSN: 2706-6495

Table 4. percentage and frequency of reporting verbs in the Kabul Times:

\begin{tabular}{lll}
\hline Verb & Frequency & Percentage \\
\hline Say & 56 & 30.2 \\
\hline Said & 12 & 12.4 \\
\hline Talk & 4 & 20 \\
\hline Focus & 13 & 2 \\
\hline Express & 15 & 3 \\
\hline Stress & 16 & 4 \\
\hline Agree & 6 & 1.40 \\
\hline Add & 10 & 1.30 \\
\hline Urge & 4 & 6.70 \\
\hline Confirm & 2 & 8.50 \\
\hline Describe & 8 & 0.85 \\
\hline Condemn & 2 & 0.70 \\
\hline Support & 9 & 0.65 \\
\hline Ask & 7 & 1.30 \\
\hline Object & 18 & 6 \\
\hline Emphasize & 19 & 4 \\
\hline Total & 201 & $100 \%$ \\
\hline
\end{tabular}

Table 5: percentage and frequency of reporting verbs in Pajhwalk.

\begin{tabular}{lll}
\hline Verb & Frequency & Percentage \\
\hline Say & 56 & 30.2 \\
\hline Claim & 12 & 12.4 \\
\hline Argue & 4 & 20 \\
\hline Allege & 13 & 2 \\
\hline Threaten & 15 & 3 \\
\hline Call on & 16 & 4 \\
\hline Address & 6 & 1.40
\end{tabular}




\begin{tabular}{lll}
\hline Tell & 10 & 1.30 \\
\hline Urge & 4 & 6.70 \\
\hline Confirm & 2 & 8.50 \\
\hline Describe & 8 & 0.85 \\
\hline Condemn & 2 & 0.70 \\
\hline Support & 9 & 0.65 \\
\hline Thank & 7 & 1.30 \\
\hline Praise & 18 & 6 \\
\hline Blame & 19 & 4 \\
\hline Total & 201 & $100 \%$
\end{tabular}

We can observe from the above two tables 4 and 5, that reporting verb said is most widely used in the both online sites. As Bell (1991) said that said or say is most reporting verb which is used and will be used in the news. We can clearly say that Kabul times used said verb more than Pajhwalk in the reports. We can divide the used verbs into three groups. Neutral verbs, approval verbs and disapproval verbs. The last two groups verbs which are used in both websites belongs' to Bell's (1991) verbs which are known as news performatives there is the fusion of the word and the act (p.207). In the above three group verbs are used to extend polarization.

\section{Labeling}

Through the using of labeling we raise to the idea of giving labels to both new activities and their actors. Van Dijk (1991) converses the same idea bellow in the term of lexicalization in which we can give names to the semantic and social actors and their activities. Lexicalization is the procedure of acts as the basis for the readers to show the world from different aspects. This framework gives different identities to the news actors rather than the others.

Through the texts of the both online news websites i.e Kabul Times and Pajhwalk is the naming of the process results in the phenomena of peace. Fowler (1991) explain the classification a 'linguistic objectification of 'allocation of a definite place' (p.58). Another types of classification are grouping objects into the larger groups. This kind of group is not neutral as it all the times conveys the ideological meaning. 
The idea of classification is steady with the Fairclough's view of the texts as the sequence of the options or some replacements from which we select that what can be best to represent our viewpoints (1995, p. 18).

The analyst follows a wide utilization of the procedure of order in the two sites with the point of building up certain 'generalizations' of 'us' and 'them'. By marking news on-screen characters and occasions in certain ways, every site attempted to closer view 'Our great deeds' and disparage the other by foregrounding 'their terrible deeds'. The exploration follows two dimensions of 'denouncing the other. The main dimension is by naming news performers. This is outlined in Table (6) beneath. The second dimension is by naming the three primary exercises in the reports.

Table 6: shows the labeling of news activities and news actors in Kabul Times and Pajhwalk.

\begin{tabular}{lll}
\hline News website & Them & We \\
\hline Terrorist & Ordinary Citizens \\
Party thugs & Educated peoples \\
Killer & Protestors \\
Mafists & Popular \\
drug abuse and drug dealers & Defenseless supporters \\
Widespread violence riots & Peaceful peoples \\
Criminals & Polite, substantial, modest, \\
Vicious criminals & moral \\
Criminal hands & Loyal youth \\
Professional & The finest young people in \\
criminals & Afghanistan \\
Committers & Victims \\
troublemakers of violence & Sacrifices \\
Ferocious gangs & \\
Pakistan & \\
USA & \\
Russia &
\end{tabular}




\begin{tabular}{ll}
\hline Opposite parties & The widespread current \\
Taliban & Young generation \\
Haqani Group & Civil powers \\
Pakistan & Party members \\
USA & Silent majority \\
Gang & The middle class \\
Corruption & The Countrywide Rescue \\
Fascist authoritarianism & Front \\
Terrorists & Educated people \\
Criminals & Civilians \\
Committers & All Citizens \\
Non peace likers & Victims \\
Peace likers & \\
&
\end{tabular}

The angels ideological rectangular of Van Dijk are obviously characterized in the table 6. The news actors of both websites with their new actors as the good contributors while the other is totally damaged with the goal of portraying different labels. Firstly, the Kabul Times presents the members of its site through the developing explanation portraying them as the normal citizens at the start and as sacrifices at the end.

However, the other is labelled as forceful. Deceitful and a supporter of the previous government. Also the word is as a cruel criminal, acquisitive, unfaithful and an enthusiast of the previous government. With the use of these kinds of nicknames, the journalists tend to proceed a type of alliance with the readers against enemies of the peace the parties or the people who don't want peace.

This study notices a kind of the growth of polarization the labels which is given to the other. Labeling the other in this study starts with the Taliban and government and neighbor countries.

Secondly, we can say that the Pajhwalk follows the same kinds of plan of labeling. Which represents the peace maker and peace lovers as the opponents of war. In the choice of our labels the journalists focus on the importance of peace. These kind of people are the educated level or educated class majority in the society. Otherwise, we can say that they represent most Afghans and that is why their ideas should be followed. 
In other hand, the word 'other' is portrayed as the faithful and obedient to the government and Taliban to make a new government. It has to be noted that here the most important or most of the labels given to the other are general such as people, government, parties and Talibans. Teo, (2000) describes that this kind of idea under the term of generalization which denotes to the postponement of the feature or actions of the exact or particular group of people which are more general and they are open ended (p. 16).

Generalization is used to minimalize the exclusivity of the leaders as individuals. With the labeling them as a general, the reporters portray the leaders as a 'unity' whose members cannot think imaginatively. The idea of generalization is accepted by the Kabul Times but in different approach. This is imitated in its labeling of its key adversaries represented by the Jahadi leaders. These leaders are not ever given a title or label in Kabul Times reports so that they are apparent as ordinary, normal, worthless of the reader's consideration. In contrast, Pajhwalk presents these leaders as exclusive figures. Which can be seen in the way where each of the leaders are labeled as following:

Examples:

1. Mohammad Hanif Atmar: part leader and presidential nominee.

2. Amr Moussa: Conference party head-leader of the popular congress party- Former Arab League chief- former presidential nominee.

\section{Conclusion:}

This study answers the two questions. The first question was about Van Dijik's application (1998) the ideological fair. In this different,

This claimed that the usage of "polarized discourse headed to the formation of in and out groups which is presenting the other in the labels. However, 'the other' is criticized by both sites by foregrounding its worse performances. The second question was concerned with the conversational performs replicating the polarization, such as the quotation and labeling. Though, it is maintained that the both expansive performs can be obviously marked out in the both sites reporting. 
According to the quotation patterns, the imitate of polarized discourse in the different forms. The first form was choice of the quotation kinds. Each site oftens quotes from their own supporters while 'the other' is silenced which is never quoted or its quoted when it is criticized. In this regard, the Kabul Times is exceptional in two different ways. The reporters make their viewpoints through the quoting of others in order to not the impartiality of standard. However, the journalists use the methods of quotations to demonstrate of their endorsement of what is quoted.

The other kind form of polarized discourse, through the quotation of patterns is the optimal of sources. Polarization is very strong in these ways in which the sources are selected. Both of the sites focuses on the elatedness of sources. They used unnamed or different speeches to explain their thoughts Kabul Times is exposed to be different from the Pajhwalk.

Third form of the polarization, is signified in the quotation patterns, which is attained over the usage of the reporting verbs. Both of the sites used different kinds of the verbs such as neutral verbs, approving verbs and disapproving verbs. The verbs which are used as an evaluative instrument through which the journalists rage his decision with the sources which are quoted.

The last personification of polarization is the labeling. Both sites tend to demote 'the other' site by the presenting through the 'critical categorization' to use the terminology of Fowler (1991, p. 138). By the labeling of the news actors and the events of both sites tend to portray the other site to appropriate the different labels.

\section{References:}

Juan, L. (2009). Intertextuality and national identity: discourse of national conflicts in daily newspapers in the United States and China. Discourse \& Society 20 (1), 85-121.

Kuo, S. and Nakamura, N. (2005). Translation or transformation? A case study of language and ideology in the Taiwanese press. Discourse \& Society 16 (3), 393-417.

Mautner, G. (2005). Time to get wired: Using web-based corpora in critical discourse analysis. Discourse \& Society 16 (6), 809-828.

Rasti, A. and Sahragard, R. (2010). Actor analysis and action delegitimation of the participants involved in Iran's nuclear power contention: A case study of The Economist. Discourse \& Society 23 (6), 729-748. 
Richardson, J. (2007). Analysing newspapers: an approach from critical discourse analysis. NewYork: Palgrave Macmillan.

Sinclair, J. (1986). Fictional worlds. In M. Coulthard (Ed.), Talking about text: Studies presented to David Brazil on his retirement (Discourse

Analysis Monographs No. 13) (pp. 43-60). Birmingham: University of Birmingham, English Language Research.

Teo, P. (2000). Racism in the news: A critical discourse analysis of news reporting in two Australian newspapers. Discourse \& Society 11 (1), 7-49.

Thetela, P. (2001). Critique discourses and ideology in newspapers reports: A discourse analysis of the South African reports on the 1998

SADC's military intervention in Lesotho. Discourse \& Society 12 (3), 347-70.

Van Dijk, T. (1988). News as discourse. Hillsdale, NJ: Erlbaum.

Van Dijk, T. (1991). Racism and the press. London: Routledge.

Van Dijk, T. (1993). Principles of critical discourse analysis. Discourse \& Society 4 (2), 249 83.

Van Dijk, T. (1996). Discourse, power and access. In C. R. Caldas-Coulthard and M. Coulthard (Eds.), Texts and practices: Readings in critical

discourse analysis (pp. 84-104). London: Roultledge.

Van Dijk, T. (1998). Opinions and ideologies in the press. In A. Bell and P. Garett (Eds.), Approaches to media discourse (pp. 21-63). Oxford: Blackwell.

Van Dijk, T. (2000). New(s) racism: A discourse analytical approach. In S. Cottle (Ed.), Race, racism and the mass media. Milton Keynes: Open

University Press.

Copyright (C) 2022 Mohammad Naeem Wisal, AJRSP. This is an Open-Access Article Distributed under the Terms of the Creative Commons Attribution License (CC BY NC) Doi: $\underline{\text { doi.org/10.52132/Ajrsp.e.2022.34.3 }}$ 